\title{
Mutual influence of malignant cells and cellular microenvironment: prospects for manipulating tumour microenvironment with nanomaterials
}

\author{
Anna M. Malkova ${ }^{1,2}$, Sergei V. Ageev ${ }^{1,2}$, Abdelsattar O. E. Abdelhalim ${ }^{2,3}$, Oleg E. Molchanov ${ }^{4}$, Dmitrii N. Maistrenko ${ }^{4}$, \\ Konstantin N. Semenov ${ }^{1,2,4}$, Vladimir V. Sharoyko ${ }^{1,2,4}$ \\ ${ }^{1}$ Pavlov University, St. Petersburg, Russia \\ ${ }^{2}$ Institute of Chemistry, St. Petersburg State University, Saint Petersburg, Russia \\ ${ }^{3}$ National Center for Social and Criminological Research, Giza, Arab Republic of Egypt \\ ${ }^{4}$ A. M. Granov Russian Research Centre for Radiology and Surgical Technologies, St. Petersburg, Russia
}

Dr. Vladimir V. Sharoyko, Pavlov University,

6-8 L. Tolstoy St., 197022, St. Petersburg, Russia
Phone: +7 (981) 936-41-51

E-mail: sharoyko@gmail.com

Citation: Malkova AM, Ageev SV, Abdelhalim AOE et al. Mutual influence of malignant cells and cellular microenvironment: prospects for manipulating tumour microenvironment with nanomaterials. Cell Ther Transplant 2021; 10(3-4): 8-18.

\section{Summary}

Development and progression of neoplasia occurs in parallel with changes in the surrounding stroma. Cancer cells may functionally reshape their microenvironment by secreting various cytokines, chemokines and generation of acidic medium. These factors contribute to differentiation of immune cells into immunosuppressive phenotype, stimulate the synthesis of a number of amino acid metabolism enzymes, growth factors, adhesion molecules, which promote invasion, angiogenesis and metastasis, and also reduce efficiency of anticancer drugs and radiation therapy. To increase effectiveness of the chemotherapy, multitargeted carbon nanomaterials may be applied. In particular, nanomaterials based on modified graphene make it possible to create multicomponent therapeutic constructs, including macromolecules, polymers, and effector agents. Initial experiments with unmodified graphenes demonstrated their toxicity associated with their accumulation in parenchymal organs and initiation of inflammatory processes. In the past few years, a series of works has been published in which the possibility of reducing the toxicity of graphene oxide through functionalisation has been demonstrated. This review summarises the experimental data on the creation of covalent and non-covalent conjugates based on graphene oxide and demonstrates their in vitro efficacy on various tumour cell lines. Separately, there are few data on the effect of nanomaterials based on graphene oxide on the tumour microenvironment.

\section{Keywords}

Tumour, microenvironment, progression, cytokines, acidosis, immune system, carbon nanomaterials.

\section{Introduction}

During the development of malignant neoplasia, a specific cellular environment is formed in the chronic inflammation site termed "inflammatory microenvironment of the tumour" (TME). This cell community consists of tumourassociated macrophages (MF), dendritic cells (DC), myeloid suppressor cells (MSC), neutrophils (NF), mast cells, natural killer cells (NK), T- and B-lymphocytes, cancer-associated fibroblasts (CAF) and endothelial cells. The interaction between tumour cells, myeloid cells and lymphocytes is a dynamic, bidirectional process and includes intercellular contacts, constant exchange of secreted soluble molecules, factors, vesicles, due to which an autonomous system is established that regulates tumour growth [1-5]. 
Neoplastic progression is associated with lack of oxygen, deficiency of nutrients causing hypoxia and development of metabolic acidosis in the tumour microenvironment. These factors promote selection of tumour cells with the gene mutations that allow them to survive under more severe microenvironmental conditions. Such adaptation of tumour cells is accompanied by increased production of various growth factors, cytokines, chemokines, which together present a triggering factor for enhancement of angiogenesis, metastases, and inhibition of local immune response. In turn, the normal TME cells also begin to secrete factors promoting tumour progression. As a result, a closed-circuit regulatory system is formed [6]. E.g., the content of IL-4 increases in TME, thus inducing differentiation of macrophages to the second-type (M2) resident cells. The M2 subpopulation may account for up to $50 \%$ of the tumour mass and contribute to activation of pro-tumourigenic processes accompanied by the synthesis of IL-1, IL-1RA, IL-4, IL-6, IL-10, IL-12, L-arginine, prostaglandin E2, TNF- $\alpha$, TGF- $\beta$, VEGF-A, and a variety of chemokines and their receptors CCL1, CCL5, CCL17, CCL22, CCL24, CCR2, CXCL10, CXCL16 [7-9]. These mediators are involved in angiogenesis, immunosuppression, and metastasis.

In tumour cells, increased production of some amino acid metabolism enzymes is revealed, e.g., of indolamine 2,3-dioxygenase, arginase-1. Activation of iNOS, as well as STAT3 transcription factor is noted, thereby initiating the differentiation of dendritic cells into tolerogenic tumour-associated dendritic cells (TADC) [10]. These cells produce TGF- $\beta$ which promotes immunosuppression by stimulating Th2, Th17 and T regulatory cells [11].

Of interest, differentiation of neutrophils in the TME structures depends on the stage of the disease. Thus, the normally pro-inflammatory neutrophils differentiate at later phase to an immunosuppressive phenotype under the influence of TGF- $\beta$ and angiotensin II [12]. The tumour-associated neutrophils synthesise collagenase IV, heparanase, elastase and matrix metalloproteinases (MMPs) which contribute to extracellular matrix degradation, tumour cell invasion and metastasis. The secreted proteinases destroy extracellular matrix, and degrade the pro-inflammatory cytokines, thus causing anti-inflammatory effects [13]. Neutrophils also produce oncostatin $M$, which enhances angiogenesis, as well as CXCL1, CXCL8, CCL-3, CXCL6, TGF- $\beta$, and prostaglandin E2 synthesis, thus supporting the neoplastic progression [14].

The CSF-1, HIF-1a, CCL2, CCL7, CXCL1 peptide factors synthesised by the TME cell populations are able to alter the metabolism of myeloid cells, leading to transition to MSC [15]. MSC enhance the synthesis of reactive oxygen species, arginase-1, prostaglandin E2, IL-4, IL-6, inhibit the function of T-lymphocytes [16], support the stemness of tumour cells [17], increase angiogenesis and metastasis [18]. It should be noted that MSC create background for spreading the tumour not only locally, but also to the target organ, inducing expression of adhesion molecules on the surface of endotheliocytes, e.g., E-selectin, intercellular adhesion molecules 1 (ICAM-1), and vascular cell adhesion molecules 1 (VCAM-1), promoting residence of tumour cells in the target organ [19].
M2 macrophages and MSCs are the main producers of IL$1 \beta$, which initiates a whole spectrum of procarcinogenic effects [20-23]. IL-1 $\beta$ provides both direct and indirect effects upon angiogenesis, by inducing the synthesis of various cytokines and angiogenesis factors [24]. Direct effects of IL-1 $\beta$ include activation of FGF- $\beta$ expression in endothelial cells [24], VEGF-A and its receptors [25], regulation of endothelial progenitor cells, thus contributing to neovascularisation [25]. IL- $1 \beta$ also affects Bv8, CCL2, and CCL3 secretion, leading to $(i)$ enhanced synthesis of VEGF-A, PLGF, bFGF by endothelial cells, (ii) VEGF-A secretion by myeloid cells (CD34+ or Flk-1+) [26], (iii) FGF1 secretion by mononuclear cells [27], (iv) IL-8 secretion by macrophages [28]. In general, IL-1 $\beta$ may affect cell differentiation, causing synthesis of either pro-inflammatory, or angiogenetic factors [28]. Immunosuppressive effect of IL- $1 \beta$ proceeds via stimulated synthesis of anti-inflammatory factors (IL-10, TGF- $\beta$, arginase-1) by tumour-associated macrophages and MSCs. This effect results into suppression of $\mathrm{T}$ cell and M1 activities [28], and the non-canonical signalling pathway of the NF- $\kappa B$ transcription factor is triggered, thus, in turn, suppressing antitumour immunity of T-regulatory cells [29]. The effect of IL- $1 \beta$ was shown to be associated with PD-L1 overexpression, an additional factor of immunity inhibition [29].

The role of immune cells in TME may be either to suppress tumour growth (antitumour TME), or to promote tumour growth (immunosuppressive TME). Thus, depending on the TME factors and type of malignancy, the immune cells may exert pro- or antitumour effects (Fig. 1) [30].

Cancer-associated fibroblasts (CAF) synthesise factor(s) inducing differentiation of macrophages to M2 and depletion of CD8+ $\mathrm{T}$ cells, which also stimulates proliferation, invasion and metastasis of tumour cells [31]. Along with cytokine production, tumour cells may activate pro-tumourigenic processes, due to metabolic acidosis in the extracellular matrix. E.g., acidification of extracellular matrix triggers p53-dependent apoptosis of surrounding cells and degradation of the basement membrane [32], along with increased secretion of cathepsin B, metalloproteinases, urokinase plasminogen activator, hydrolysing components of the extracellular matrix [33]. Also, acidification of extracellular matrix alters the lysosomal distribution, thus further enhancing secretion of proteinases causing destruction of extracellular matrix [34] and disruption of intercellular adhesion contacts by degradation of E-cadherin [35].

Several studies suggest acidosis to be a factor of immune therapy efficiency, as shown in murine models of melanoma and pancreatic adenocarcinoma, where the increased TME acidity correlated with inhibited antitumour T cell-mediated immunity, associated with lower efficacy of immune drugs $[36,37]$.

Increased acidity of TME leads to decreased efficiency of anticancer drugs, due to decreased transfer of drugs into the cells. For example, anthracyclines (doxorubicin), anthraquinones and alkaloids are weak bases and require optimal $\mathrm{pH}$ range (7.5-9.5) for their transmembrane transport [38-40]. Under these conditions, activity of a well-known glycoprotein transporter (pGP) is enhanced, thus promoting efflux of anticancer drugs from malignant cells. This effect was 
Tumour-suppressive immune microenvironment

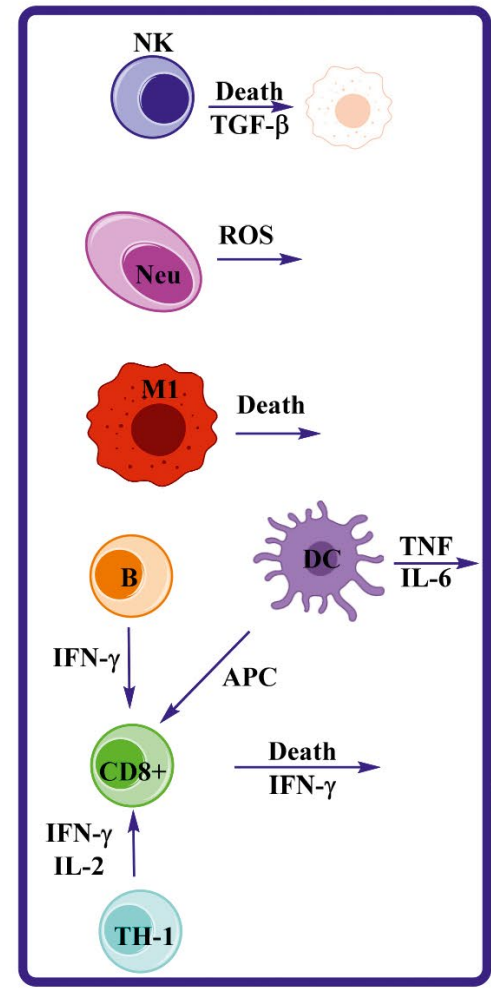

Immune

suppressive microenvironment

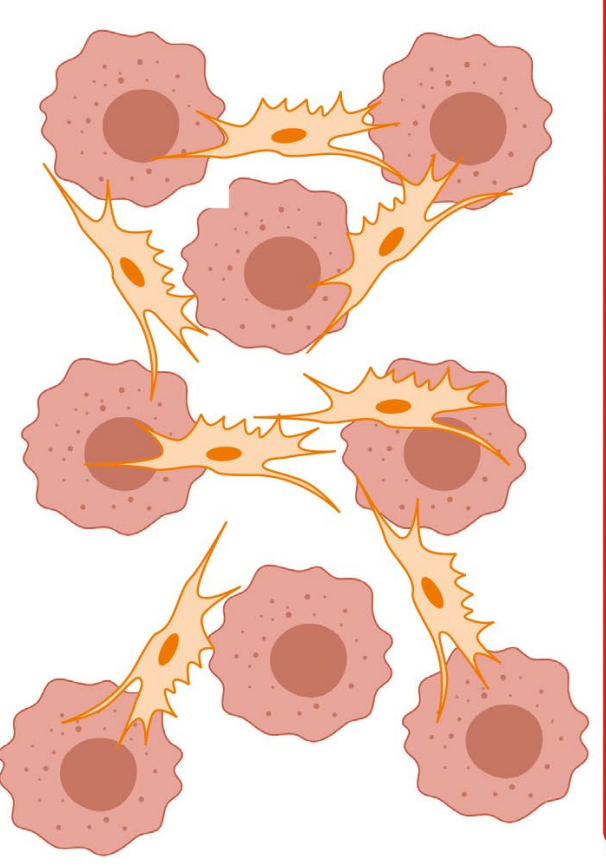

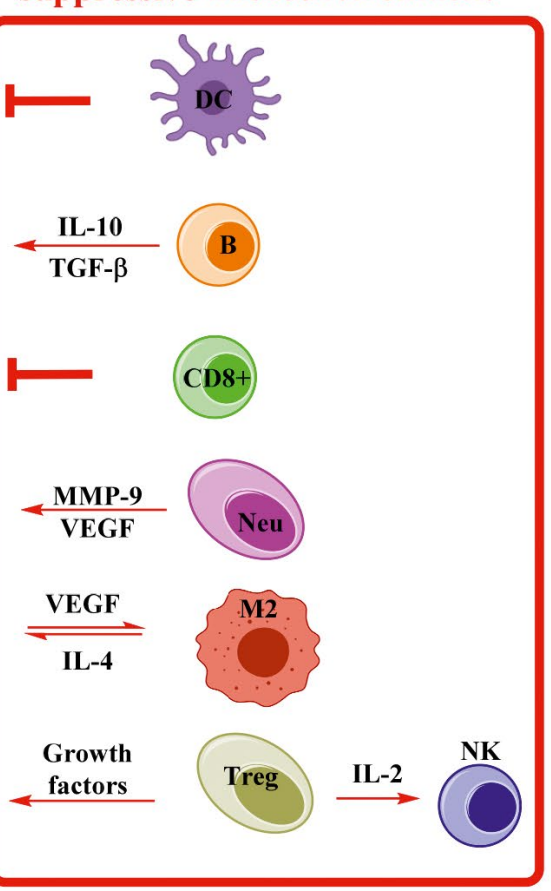

Figure 1. Influence of various immune cell populations upon TME

Abbreviations: NK, natural killers; Neu, neutrophils; MI, type I macrophages; DC, dendritic cells.

observed in tumour cells adapted for low extracellular $\mathrm{pH}$, with acquired TP53 gene mutations [41-43]. These adaptive processes cause multidrug resistance and limit the choice of therapeutic options.

Hence, malignant cells may stimulate differentiation of tumour-associated immune cells to immunosuppressive phenotypes by synthesising a wide range of signalling molecules. In turn, these immune cells produce anti-inflammatory factors, growth factors, proteinases, enhance expression of adhesion molecules, causing invasion and metastasis of tumours, activation of angiogenesis. TME acidification is not only a factor leading to selection of the most resistant and aggressive tumour phenotypes, but it also induces destruction of intercellular contacts and extracellular matrix, which ultimately triggers the processes of invasion and metastasis.

Mutual influence of tumour cells and normal TME populations promotes development of cell associations, and their extracellular milieu protects from external impacts, e.g., anticancer therapy, immune surveillance. Even a small number of tumour cells forms a microenvironment resistant to antitumour therapy, especially if they are represented by stem or 'dormant' cells. Hence, a prevalence of the distinct component of the cellular microenvironment presumes differentiated approach to treatment. The strategic purpose in oncology is to transform cancer into a long-term chronic disease which is well controlled by the low-toxicity approaches. To implement this task, three areas of research could be highlighted: (i) a search for specific key target molecules, in order to create targeted drugs; (ii) personalisation of treatment programs based on molecular and cellular characteristics of the tumour, and individual clinical prognosis; (iii) use of nanomaterials when creating novel drugs, thus providing higher efficiency of treatment. The latter approach may increase concentrations of active substances in the tumour foci and reduce the drug toxicity. Long-term studies provide convincing evidence that carcinogenesis is a multistage multicomponent process, including disturbances of apoptosis, proliferation, angiogenesis and cell metabolism leading to the formation of altered pathological microenvironment.

Multimodality of carcinogenesis requires usage of combined treatment methods aimed at different molecular targets. In the past ten years, a series of nanomaterials has been developed in various laboratories around the world that have great potential for therapeutic use in oncology, e.g., liposomes, polymer carriers, carbon nanoparticles, iron oxide and gold nanoparticles. Currently, there is a technical opportunity of creating structures that would deliver active substances to the target cells and undergo biodegradation. However, the mentioned nanocarriers have a number of disadvantages. Liposomes, polymers, dendrimers can provide a significant decrease in overall toxicity of cytotoxic drugs, but they have a low potential in terms of targeted delivery. Carbon nanomaterials make it possible to create multicomponent and multitarget therapeutic constructs. Graphene and its derivatives are considered the most promising carbon nanomaterials for these purposes. 


\section{Current experience with graphene carriers}

Initial experiments with unmodified graphene demonstrated its systemic toxicity $[44,45]$ associated with accumulation in lungs [46], reticuloendothelial system including liver and spleen $[47,48]$ and provoking an inflammatory response [49]. Recent studies have shown that modified graphene oxide is promising for manipulating the tumour microenvironment; however, an analysis of the literature suggests that research in this area has just begun. For example, the use of graphene oxide functionalised with polyethylene glycol (GO-PEG) in photodynamic therapy led to a decrease in the interleukin-4-dependent polarisation of M2 in macrophages of the tumour microenvironment. The antitumour action of GO-PEG was to reduce the migration and invasion of subcutaneous osteosarcoma cells in mice [50]. In [51], the combined effect of low-frequency ultrasound therapy and graphene oxide-doxorubicin (GO-DOX) conjugate on local damage to endothelial cells lining the neovascular network was shown. This effect increased the penetration of the GO-DOX conjugate into the interstitial space of mouse liver carcinoma through damaged capillaries. Over past few years, a series of works was published at the Department of General and Bioorganic Chemistry (Pavlov University, St. Petersburg) which demonstrated an opportunity of reducing toxicity to acceptable level, due to functionalisation of the graphene carrier [52-54]. Moreover, the graphene-based nanomaterials (GBN) have been shown to have a number of advantages: stimulation of immune response, inhibition of tumour stem cells, regulation of angiogenesis and hypoxia [55]. In particular, it should be noted that the GBNs exhibit photodynamic and photothermal activity, and can be effectively used as nanoplatforms for targeted delivery of cytostatic drugs.

Graphene is known to consist of $\mathrm{sp}^{2}$-hybridised carbon atoms forming two-dimensional nanolayers, while graphene oxide (GO) contains various oxygen-containing oxygen functional groups: (i) carboxyl, carbonyl, and lactol, located at the edges of GO layers; (ii) epoxy and hydroxyl groups distributed on the surface of the GO plane [56-61] (Fig. 2). Reduced GO (rGO) is a variant of GO in which most of the oxygen-containing functional groups are reduced by means of hydrazine hydrate or biomolecules [54, 62].

A graphene monolayer was obtained in 2004 by A. Geim and K. Novoselov [63], while GO was first synthesised in 1859 by B. Brodie by oxidising graphite using a mixture of oxidising agents (potassium chlorate and fuming nitric acid) [64]. However, the most effective method was developed by W. Hammers and R. Offeman in 1957, with a mixture of sulphuric acid, sodium nitrate and potassium permanganate [65]. GO functionalisation can be carried out using various reactions (Fig. 3): amidation, esterification, 1,3-dipolar cycloaddition, halogenation, as well as through non-covalent functionalisation through the formation of hydrogen bonds, $\pi-\pi$ stacking and hydrophobic interactions. These reactions make it possible to obtain unique nanomaterials having a medical potential in cancer treatment [66], delivery of drugs and biomolecules [67, 68], development of biosensors [69], as well as substances with antiviral [70], antibacterial [71]

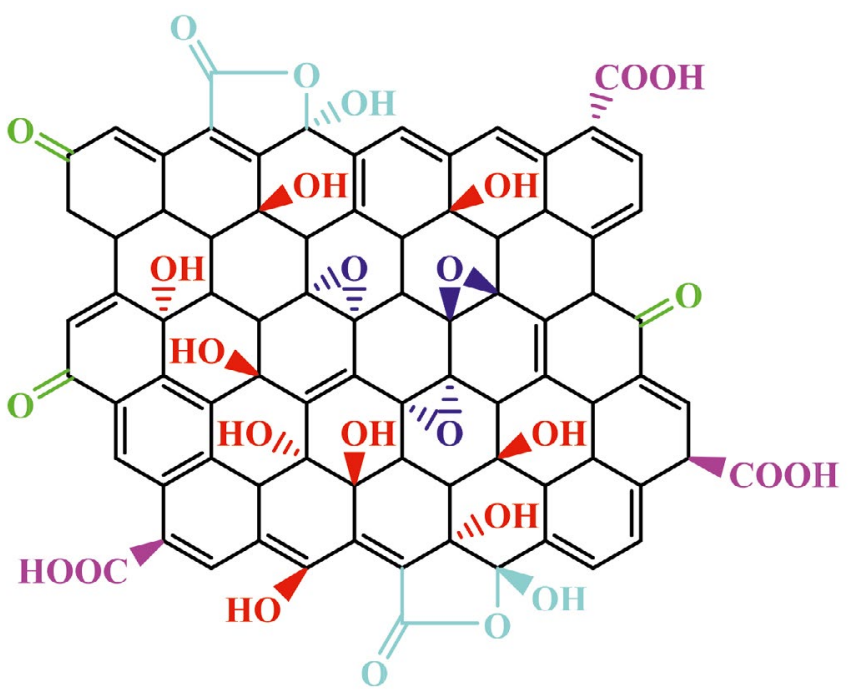

Figure 2. General structure of graphene oxide

and antifungal activity [72]. Among GBN, GO has the greatest potential for use in medicine for the following reasons: (i) GO contains various functional groups that allow further surface functionalisation; (ii) functionalisation of GO increases its biocompatibility; (iii) the presence of oxygen-containing functional groups ensures stability of aqueous GO dispersions.

Analysis of the literature revealed a number of research works devoted to synthesis and biological activity of GBNbased conjugates. Zhang et al. [73] reported that covalent GO functionalisation with sulphonic acid and folic acid $\left(\mathrm{GO}-\mathrm{SO}_{3} \mathrm{H}-\mathrm{FA}\right)$ groups increased the specific cytotoxicity for MCF-7 cells (breast cancer-derived strain). Conjugation of doxorubicin (DOX) and camptothecin (CPT) with GO through its non-covalent functionalisation (due to $\pi-\pi$ stacking and hydrophobic interactions) significantly increases therapeutic efficacy as compared to individual drugs. The $\mathrm{CPT}$ and DOX loading in the mixed GO-SO ${ }_{3} \mathrm{H}-\mathrm{FA}-\mathrm{CPT}-$ DOX conjugate was $4.5 \%$ and $400 \%$, respectively.

Wang et al. [67] demonstrated that covalent functionalisation of GO with chlorotoxin (CTX) increases the efficiency of drug delivery to C6 glioma cells. At the same time, non-covalent DOX attachment with a loading of $570 \mathrm{mg}$ DOX per gram of CTX-GO significantly increases efficiency of the conjugate (the release of the cytostatic drug was pH-dependent). Fan et al. [74] synthesised a covalent GObased conjugate with adipic acid dihydrazide and sodium alginate (SA). Then, DOX $\cdot \mathrm{HCl}$ was attached non-covalently to GO-SA. The maximum DOX loading was $1.8 \mathrm{mg}$ per $1 \mathrm{mg}$ GO-SA. The highest drug release rate was observed at pH 5.0. Cytotoxicity testing with HeLa (cervical carcinoma) cell line showed that the GO-SA conjugate is not cytotoxic, while GO-SA/DOX exhibits cytotoxicity due to the specific effect on CD44 receptors.

Qin et al. [75] synthesised GO non-covalently conjugated with polyvinylpyrrolidone (PVP, $\mathrm{M}=30 \mathrm{kDa}$ ), and then folic acid (FA) was covalently attached through the formation of an amide bond (carboxyl groups of GO and amino groups of FA). Next, the authors performed non-covalent DOX loading (due to $\pi-\pi$ stacking and hydrophobic interactions). 


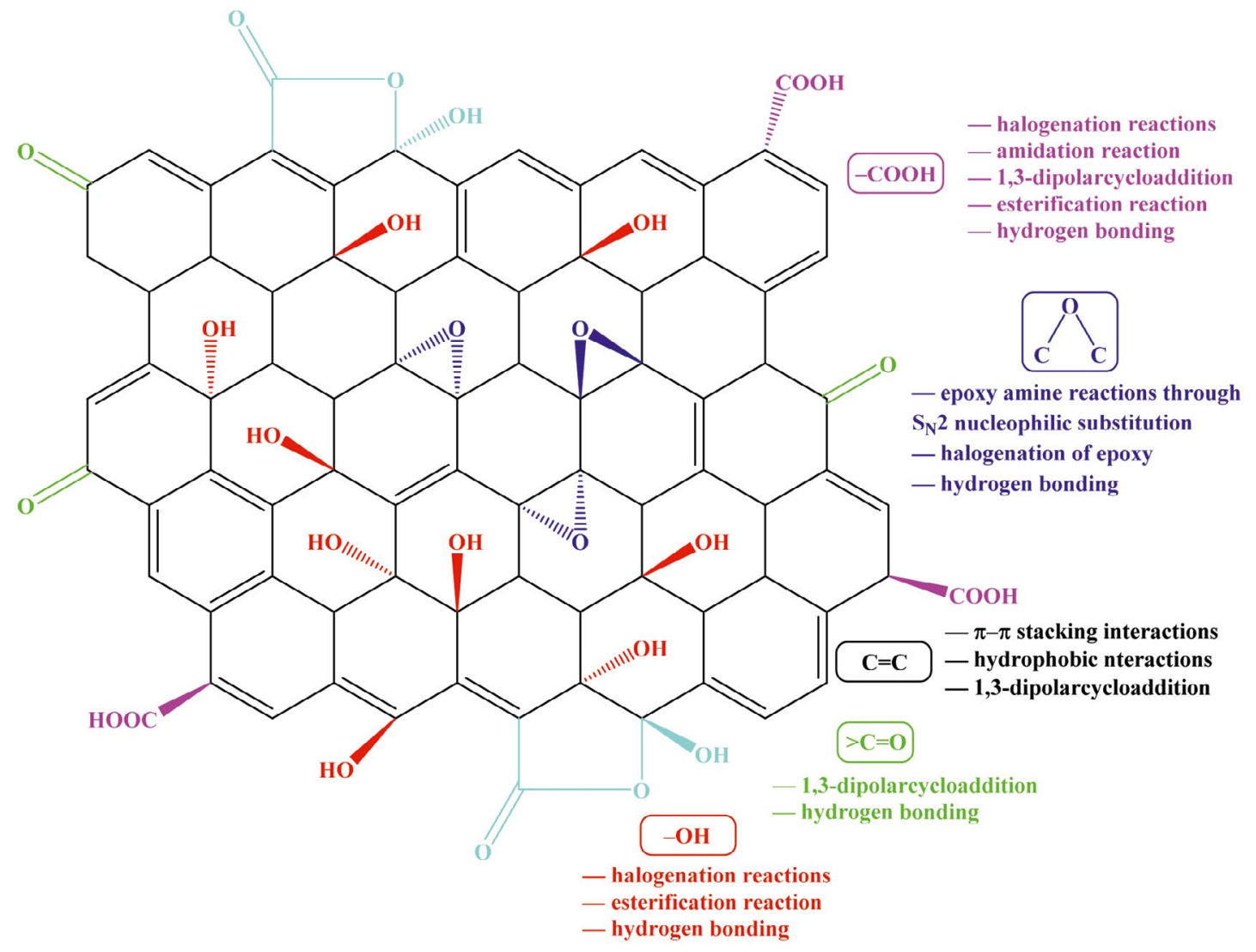

Figure 3. Basic ways to functionalise graphene oxide

The calculated value of the DOX loading on the FA-GO-PVP was 107.5 wt. \%. The resulting conjugate demonstrated high antitumour efficacy against HeLa cells. Huang et al. [76] described the ability of FA-functionalised GO to efficiently bind the chlorine $e_{6}$ photosensitiser for photodynamic therapy. Tiwari et al. [77] used the GO-PVP noncovalent conjugate for double noncovalent addition of quercetin (QS) and gefitinib (GF) and compared it with the GO-PVP-QS and GO-PVP-GF conjugates. The authors found that the combined loading of the drugs showed higher cytotoxicity against PA-1 (ovarian cancer) cell line compared to individual drugs. The amount of QS and GF in GO-PVP-QS-GF was $20 \%$ and $46 \%$, respectively.

Deb et al. [78] functionalised GO with polyethylene glycol (PEG), FA, and CPT via non-covalent $\pi-\pi$ stacking interactions (CPT loading was $45 \%$ ). The resulting conjugate $\left(C=100 \mu \mathrm{g} \cdot \mathrm{ml}^{-1}\right)$ caused the death of $76 \%$ of cells compared with the control when using the MCF-7 cell line [78]. The same group functionalised GO with the natural polymer chitosan (CS) and FA, to deliver CPT and 3,3'-diindolylmethane (DIM). The resulting conjugate (GO-CS-FA-CPTDIM) demonstrated high cytotoxicity against the MCF-7 cell line $(95.7 \%$ decrease in cell viability), which was significantly higher compared to individual DIM preparations (42.4\%) and CPT (52.6\%) [79]. Pei et al. [80] showed that simultaneous functionalisation of the GO surface with PEG (pGO) (pGO-CP-DOX, mass ratio: 1: 0.376: 0.376) with cisplatin (CP) and DOX leads to increased cytotoxicity towards Cal-27 (human squamous carcinoma) and MCF7 cell lines. The authors observed higher inhibition of cell proliferation for the pGO-CP-DOX conjugate compared to individual preparations: $\mathrm{IC}_{50}(\mathrm{MCF}-7)=14.5 \mu \mathrm{g} \cdot \mathrm{ml}^{-1}$ for pGO-CP-DOX, $22.5 \mu \mathrm{g} \cdot \mathrm{ml}^{-1}$ for $\mathrm{pGO}-\mathrm{DOX}$, and $22 \mu \mathrm{g} \cdot \mathrm{ml}^{-1}$ for pGO-CP [80]. Bullo et al. [81] demonstrated the ability of GO functionalisation using PEG, FA, and anticancer drugs: protocatechuic acid (23.5\% PCA) and chlorogenic acid $(18.3 \% \mathrm{CA})$. The authors investigated the effect of the GO-PEG-FA-PCA-CA conjugate on the HT29 (colon cancer) and HepG2 (liver cancer) cell lines. Cytotoxicity trials showed the following results: $\mathrm{IC}_{50}(\mathrm{HT} 29)=50.7 \mu \mathrm{g} \cdot \mathrm{ml}^{-1}, \mathrm{IC}_{50}$ $\left(\right.$ HepG2) $=40.4 \mu \mathrm{g} \cdot \mathrm{ml}^{-1}$ [81]. Gong et al. [82] demonstrated that fluorinated graphene (FG) can be used to load a mixture of DOX and CPT after CS covalent functionalisation; DOX and CPT loading were $110 \%$ and $25 \%$, respectively. The resulting FG-CS-DOX-CPT conjugate demonstrated a $60 \%$ and $75 \%$ decrease in the viability of HeLa cells with simultaneous laser irradiation (wavelength $808 \mathrm{~nm}$ ) [82]. Gong et al. [83] evaluated the ability of non-covalent FG conjugation with a cytostatic DOX loading as high as $200 \%$. The FGDOX conjugate at $30 \mu \mathrm{g} \cdot \mathrm{ml}^{-1} \mathrm{drug}$ content reduced HeLa cell line viability to $94 \%$ after $48 \mathrm{~h}$ of incubation [83].

In an in vivo study, Shim et al. [84] showed that rGO functionalised with low-molecular weight heparin (LHT7) acts as a targeted drug for the delivery of DOX. The rGO-LHT7-DOX conjugate with rGO: DOX mass ratios of 2, 1, 0.5, 0.1 demonstrated a high antitumour effect at the KB human carcinoma cell line (cell viability was decreased by $61.1 \%$ ), along with significant decrease in tumour size by $(92.5 \pm 3.1) \%$ [84]. Table 1 shows the results of studying cytotoxic conjugates based on GBN and cytostatic drugs. 
Table 1. Cytotoxicity of GBN and non-covalently linked cytostatic drugs

\begin{tabular}{|c|c|c|c|c|c|}
\hline GBN type & Cytostatic loading & $\begin{array}{l}\text { Cell lines or type } \\
\text { of cancer }\end{array}$ & $\begin{array}{l}\text { Applied } \\
\text { method }\end{array}$ & $\begin{array}{l}\text { Conjugate concentrations and } \mathrm{IC}_{50} \\
\text { or cytotoxic effect (\%) compared to } \\
\text { control at highest concentration }\end{array}$ & Reference \\
\hline $\begin{array}{l}\text { G0-sulphonic acid } \\
\text { groups-folic acid } \\
\text { (GO-SO } \mathrm{H}-\mathrm{FA}) ; \\
\mathrm{GO}-\mathrm{FA}^{-}\end{array}$ & $\begin{array}{l}\text { Dual drug loading: } \\
\text { camptothecin (CPT) } \\
(4.5 \%) \text { and DOX ( } 400 \%) \text {. }\end{array}$ & $\begin{array}{l}\text { MCF-7 (human } \\
\text { breast adenocar- } \\
\text { cinoma) }\end{array}$ & WST-8 & $\begin{array}{l}C=2 \text { and } 20 \mu \mathrm{g} \cdot \mathrm{ml}^{-1} \text { for }\left(\mathrm{GO}-\mathrm{SO}_{3} \mathrm{H}-\mathrm{DOX}-\right. \\
\mathrm{FA}), \text { cytotoxicity }=20 \% \text { and for } \mathrm{GO}-\mathrm{FA}- \\
\text { DOX (\% cytotoxicity }=67 \%) \\
C=0.002,0.02 \text { and } 0.2 \mu \mathrm{g} \cdot \mathrm{ml}^{-1} \text { for } \\
\text { (G0-FA-D0X-CPT) of } \% \text { cytotoxicity }= \\
22 \% \text { and }(\mathrm{GO}-\mathrm{FA}-\mathrm{CPT}) \\
\% \text { cytotoxicity }=26 \%\end{array}$ & [73] \\
\hline $\begin{array}{l}\text { G0-chlorotoxin } \\
\text { (G0-CTX) }\end{array}$ & $\begin{array}{l}\text { DOX loading is } 570 \mathrm{mg} \\
\text { per g G0-CTX }\end{array}$ & C6 (glioma cells) & CCK-8 & $\begin{array}{l}C=1-5 \mu \mathrm{g} \cdot \mathrm{ml}^{-1} \\
\% \text { of cytotoxicity }=60 \%\end{array}$ & [67] \\
\hline $\begin{array}{l}\text { G0-sodium } \\
\text { alginate (GO-SA) }\end{array}$ & $\begin{array}{l}\text { DOX loading is } 1.8 \mathrm{mg} \\
\text { per mg G0-SA }\end{array}$ & HeLa cells & MTT & $\begin{array}{l}C=5-20 \mu \mathrm{g} \cdot \mathrm{ml}^{-1} \\
\% \text { of cytotoxicity }=69 \%\end{array}$ & [74] \\
\hline $\begin{array}{l}\text { G0 nanoparticles } \\
\text { sized } 50 \times 50 \mathrm{~nm}^{2}\end{array}$ & $\begin{array}{l}\text { Cisplatin (CP) loading } \\
\text { not determined }\end{array}$ & $\begin{array}{l}\text { A549 (lung } \\
\text { adenocarcinoma) }\end{array}$ & WST-8 & $\begin{array}{l}C=2.5-30 \mu \mathrm{g} \cdot \mathrm{ml}^{-1} \\
\% \text { of cytotoxicity }=90 \%\end{array}$ & [85] \\
\hline $\begin{array}{l}\text { G0-polyethylene } \\
\text { glycol-folic acid } \\
\text { (G0-PEG-FA) }\end{array}$ & $\begin{array}{l}\text { Camptothecin (CPT) } \\
\text { loading is } 45 \%\end{array}$ & MCF-7 & MTT & $\begin{array}{l}C=20-100 \mu \mathrm{g} \cdot \mathrm{ml}^{-1} \\
\% \text { of cytotoxicity }=76 \%\end{array}$ & [78] \\
\hline $\begin{array}{l}\mathrm{C} 0-\mathrm{Fe}_{3} \mathrm{O}_{4}-\beta-\mathrm{Cyclo}^{-} \\
\text {dextrin }\end{array}$ & $\begin{array}{l}\text { DOX loading is } 37.4 \% ; \\
\text { MTX loading is } 23.4 \%\end{array}$ & $\begin{array}{l}\text { K562 } \\
\text { (leukaemia) }\end{array}$ & MTT & $\begin{array}{l}C=2-16 \mu \mathrm{g} \cdot \mathrm{ml}^{-1} \\
\% \text { of cytotoxicity (DOX) }=65 \% \\
\% \text { of cytotoxicity (MTX) }=55 \%\end{array}$ & [86] \\
\hline G0-PEG-FA & $\begin{array}{l}\text { Loading of protoca- } \\
\text { techuic acid (PCA) is } \\
23.47 \% \text { and chlorogenic } \\
\text { acid (CA) loading is } \\
18.33 \%\end{array}$ & $\begin{array}{l}\text { HT29 (colon } \\
\text { cancer), HepG2 } \\
\text { (hepatocellular } \\
\text { carcinoma) }\end{array}$ & MTT & $\begin{array}{l}C=1.56-100 \mu \mathrm{g} \cdot \mathrm{ml}^{-1} \\
\% \text { of cytotoxicity }(\mathrm{HT29})=58 \% \\
\mathrm{IC}_{50}(\mathrm{HT29})=50.69 \mu \mathrm{g} \cdot \mathrm{ml}^{-1} \text {; } \\
\% \text { of cytotoxicity }(\mathrm{HepG2})=61 \% \\
\mathrm{IC}_{50}(\mathrm{HepG} 2)=40.39 \mu \mathrm{g} \cdot \mathrm{ml}^{-1}\end{array}$ & [81] \\
\hline $\begin{array}{l}\text { G0-FA-bovine } \\
\text { serum albumin } \\
\text { (G0-FA-BSA) }\end{array}$ & $\begin{array}{l}\text { D0X loading is } 437.43 \mu \mathrm{g} \\
\text { per } 1 \mathrm{mg} \text { G0-FA-BSA }\end{array}$ & $\begin{array}{l}\text { MCF-7 } \\
\text { (FA-receptor- } \\
\text { positive) } \\
\text { A549 } \\
\text { (FA-receptor- } \\
\text { negative) }\end{array}$ & MTT & $\begin{array}{l}C=0.01-20 \mu \mathrm{g} \cdot \mathrm{ml}^{-1} \\
\mathrm{IC}_{50}(\mathrm{MCF}-7,24 \mathrm{~h})=8.9 \pm 0.7 \mu \mathrm{g} \cdot \mathrm{ml}^{-1} \\
\mathrm{IC}_{50}(\mathrm{MCF}-7,48 \mathrm{~h})=0.048 \pm 0.010 \mu \mathrm{g} \cdot \mathrm{ml}^{-1} \\
(\% \text { of cytotoxicity }=83 \%) \\
\mathrm{IC}_{50}(\mathrm{~A} 549,24 \mathrm{~h})=5.3 \pm 0.7 \mu \mathrm{g} \cdot \mathrm{ml}^{-1} \\
\mathrm{IC}_{50}(\mathrm{~A} 549,48 \mathrm{~h})=0.279 \pm 0.037 \mu \mathrm{g} \cdot \mathrm{ml}^{-1} \\
(\% \text { of cytotoxicity }=78 \%)\end{array}$ & [87] \\
\hline $\begin{array}{l}\text { FA-G0-PVP (folic } \\
\text { acid-G0-polyvinyl } \\
\text { pyrrolidone, } \\
M=30 \mathrm{kDa} \text { ) }\end{array}$ & DOX loading is $107.5 \%$ & HeLa cells & MTT & $\begin{array}{l}2 \mu \mathrm{g} \cdot \mathrm{ml}^{-1} ; 20 \mu \mathrm{g} \cdot \mathrm{ml}^{-1} \\
\text { (\% of cytotoxicity }=71 \% \text { ) }\end{array}$ & [75] \\
\hline $\begin{array}{l}\text { Fluorinated G0 } \\
\text { (FG0) }\end{array}$ & DOX loading is $~ 200 \%$ & HeLa cells & MTT & $\begin{array}{l}C=1.11-30 \mu \mathrm{g} \cdot \mathrm{ml}^{-1} \\
(\% \text { of cytotoxicity }(24 \mathrm{~h})=70 \%) \\
(\% \text { of cytotoxicity }(48 \mathrm{~h})=94 \%)\end{array}$ & [83] \\
\hline $\begin{array}{l}\text { Pegylated folate } \\
\text { and peptide- } \\
\text { modified G0 } \\
\text { (PEG-FA-Pep-G0) }\end{array}$ & CPT loading is $90 \%$ & HeLa cells & MTT & $\mathrm{IC}_{50}=3.1 \mu \mathrm{M}$ & [88] \\
\hline $\begin{array}{l}\text { Graphene quan- } \\
\text { tum dots-carbox- } \\
\text { ymethylcellulose } \\
\text { hydrogel (GOD- } \\
\text { CMC) }\end{array}$ & $\begin{array}{l}\text { DOX loading depends } \\
\text { on GOD } \\
\text { GOD (10\%)-CMC } 4.5 \% \text {; } \\
\text { GOD (20\%)-CMC } 5.5 \% ; \\
\text { GOD (30\%)-CMC 6\% }\end{array}$ & K562 & MTT & $\begin{array}{l}C=2-32 \mu \mathrm{g} \cdot \mathrm{ml}^{-1} . \\
\mathrm{IC}_{50}=5.1 \mu \mathrm{g} \cdot \mathrm{ml}^{-1} \\
\text { (\% of cytotoxicity }=93 \%)\end{array}$ & [89] \\
\hline $\begin{array}{l}\text { G0-PVP and } \\
\text { G0- } \beta \text {-cyclodextrin } \\
\text { (CD) }\end{array}$ & $\begin{array}{l}\text { Antineoplastic drug SN- } \\
38 \text { (7-ethyl-10-hydroxy- } \\
\text { camptothecin). } \\
\text { Loading: in } 1 \mathrm{~g} \text { G0-PVP } \\
\text { is } 0.17 \mathrm{~g} \text { SN-38; in } 1 \mathrm{~g} \\
\mathrm{CO}-\beta-\mathrm{CD} \text { is } 0.14 \mathrm{~g} \text { SN-38 }\end{array}$ & MCF-7 & MTT & $\begin{array}{l}C=5 \text { and } 10 \mu g \cdot \mathrm{ml}^{-1} . \\
\mathrm{IC}(\mathrm{GO}-\mathrm{PVP}-\mathrm{SN}-38)=97 \mu \mathrm{M} ; \\
(\% \text { of cytotoxicity }=68 \%) . \\
\mathrm{IC}(\mathrm{CO}-\beta-\mathrm{CD}-\mathrm{SN}-38)=170 \mu \mathrm{M} ; \\
\text { (\% of cytotoxicity }=65 \%)\end{array}$ & [90] \\
\hline
\end{tabular}




\section{Conclusion}

Current data provide sufficient results concerning molecular and cellular events providing mutual influence of tumour cells and TME cells, as well as factors of cancer progression. It has been shown that the tumour cells per se and their cellular TME create an integrated system that promotes tumour progression and development of multiple drug resistance.

Thus, the following requirements must be met for modern therapeutic agents: targeted action, polyfunctionality with respect to ability of loading various molecules on the GBN surface, low toxicity, opportunity of selective inactivation of immunosuppressive components in the TME. The last issue deserves special attention. The chance to resolve this complex problem is shown by the example of GBN usage.

\section{List of abbreviations}

IL - interleukin

TNF- $\alpha$ - tumour necrosis factor alpha

TGF- $\beta 1$ - transforming growth factor receptor- $\beta 1$

VEGF-A - vascular endothelial growth factor A

$\mathrm{CAF}$ - cancer-associated fibroblasts

CCL - C-C motif ligand

CCR2 - C-C chemokine receptor type 2

CPT - camptothecin

CSF-1 - the colony stimulating factor 1

CTX - chlorotoxin

CXCL - the chemokine (C-X-C motif) ligand

DOX - doxorubicin

FA - folic acid

GBN - graphene-based nanomaterials

$\mathrm{GO}$ - graphene oxide

iNOS - Inducible nitric oxide synthase

bFGF - basic fibroblast growth factor

FGF1 - fibroblast growth factor 1

HIF-1a - hypoxia inducible factor 1 subunit alpha

PD-L1 - ligand of programmed death-1 receptor

PLGF - placental growth factor

STAT3 - signal transducer and activator of transcription 3

Th - T helper cells

TME - tumour microenvironment

\section{Acknowledgement}

This work was financially supported by the Ministry of Health of the Russian Federation (state assignment Э.032021; 121040200136-0).

\section{Conflict of interests}

The authors declared no potential conflict of interest.

\section{References}

1. Voronov E, Dotan S, Krelin Y, Song X, Elkabets M, Carmi Y, et al. Unique versus redundant functions of IL-1a and IL- $1 \beta$ in the tumor microenvironment. Front Immunol. 2013; 4:177. doi: 10.3389/fimmu.2013.00177
2. Apte RN, Krelin Y, Song X, Dotan S, Recih E, Elkabets M, et al. Effects of micro-environment- and malignant cell-derived interleukin-1 in carcinogenesis, tumour invasiveness and tumour-host interactions. Eur J Cancer. 2006; 42:751759. doi: 10.1016/j.ejca.2006.01.010

3. Apte RN, Dotan S, Elkabets M, White MR, Reich E, Car$\mathrm{mi} \mathrm{Y}$, et al. The involvement of IL-1 in tumorigenesis, tumor invasiveness, metastasis and tumor-host interactions. Cancer Metastasis Rev. 2006; 25:387-408. doi: 10.1007/s10555006-9004-4

4. Farc O, Cristea V. An overview of the tumor microenvironment, from cells to complex networks (Review). Exp Ther Med. 2021; 21:1-1. doi: 10.3892/ETM.2020.9528

5. Joyce JA, Fearon DT. T cell exclusion, immune privilege, and the tumor microenvironment. Science. 2015; 348:74-80. doi: 10.1126/SCIENCE.AAA6204

6. Hinshaw DC, Shevde LA The tumor microenvironment innately modulates cancer progression. Cancer Res. 2019; 79:4557-4567. doi: 10.1158/0008-5472.CAN-18-3962

7. Biswas SK, Mantovani A. Macrophage plasticity and interaction with lymphocyte subsets: cancer as a paradigm. Nat Immunol. 2010 1110. 2010; 11:889-896. doi: 10.1038/ni.1937

8. Qian BZ, Pollard JW. Macrophage diversity enhances tumor progression and metastasis. Cell. 2010; 141:39-51.

doi: 10.1016/J.CELL.2010.03.014

9. Mantovani A, Sica A, Sozzani S, Allavena P, Vecchi A, Locati $\mathrm{M}$. The chemokine system in diverse forms of macrophage activation and polarization. Trends Immunol. 2004; 25:677-686. doi: 10.1016/J.IT.2004.09.015

10. Sumpter TL, Dangi A, Matta BM, Huang C, Stolz DB, Vodovotz Y, et al. Hepatic stellate cells undermine the allostimulatory function of liver myeloid dendritic cells via STAT3-dependent induction of IDO. J Immunol. 2012; 189:3848-3858. doi: 10.4049/jimmunol.1200819

11. Collin M, Bigley V. Human dendritic cell subsets: an update. Immunology. 2018; 154:3-20. doi: 10.1111/imm.12888

12. Fridlender ZG, Albelda SM. Tumor-associated neutrophils: Friend or foe? Carcinogenesis. 2012; 33:949-955. doi: $10.1093 /$ carcin/bgs123

13. Schauer C, Janko C, Munoz LE, Zhao Y, Kienhöfer D, Frey B, et al. Aggregated neutrophil extracellular traps limit inflammation by degrading cytokines and chemokines. Nat Med. 2014; 20:511-517. doi: 10.1038/nm.3547

14. Demers M, Wong SL, Martinod K, Gallant M, Cabral JE, Wang Y, et al. Priming of neutrophils toward NETosis promotes tumor growth. Oncoimmunology. 2016; 5. doi: $10.1080 / 2162402 X .2015 .1134073$

15. Hossain F, Al-Khami AA, Wyczechowska D, Hernandez $\mathrm{C}$, Zheng L, Reiss $\mathrm{K}$, et al. Inhibition of fatty acid oxidation modulates immunosuppressive functions of myeloid-derived suppressor cells and enhances cancer therapies. Cancer Immunol Res. 2015; 3:1236-1247. doi: 10.1158/2326-6066. CIR-15-0036 
16. Kumar V, Patel S, Tcyganov E, Gabrilovich DI. The nature of myeloid-derived suppressor cells in the tumor microenvironment. Trends Immunol. 2016; 37:208-220. doi: 10.1016/j. it.2016.01.004

17. Guan J, Chen J. Mesenchymal stem cells in the tumor microenvironment (Review). Biomed Rep. 2013; 1:517-521. doi: 10.3892/BR.2013.103

18. Condamine T, Ramachandran I, Youn JI, Gabrilovich DI. Regulation of tumor metastasis by myeloid-derived suppressor cells. Annu Rev Med. 2015; 66:97-110. doi: 10.1146/ annurev-med-051013-052304

19. Shi H, Zhang J, Han X, Li H, Xie M, Sun Y, et al. Recruited monocytic myeloid-derived suppressor cells promote the arrest of tumor cells in the premetastatic niche through an IL- $1 \beta$-mediated increase in E-selectin expression. Int J Cancer. $2017 ; 140: 1370-1383$. doi: $10.1002 /$ ijc. 30538

20. Song X, Krelin Y, Dvorkin T, Bjorkdahl O, Segal S, Dinarello CA, et al. CD11b + /Gr-1 + immature myeloid cells mediate suppression of $\mathrm{T}$ cells in mice bearing tumors of IL-1 $\beta$-secreting cells. J Immunol. 2005; 175:8200-8208. doi: $10.4049 /$ jimmunol.175.12.8200

21. Elkabets M, Ribeiro VSG, Dinarello CA, Ostrand-Rosenberg S, Di Santo JP, Apte RN, et al. IL-1 $\beta$ regulates a novel myeloid-derived suppressor cell subset that impairs NK cell development and function. Eur J Immunol. 2010; 40:33473357. doi: $10.1002 /$ eji.201041037

22. Bunt SK, Sinha P, Clements VK, Leips J, Ostrand-Rosenberg S. Inflammation induces myeloid-derived suppressor cells that facilitate tumor progression. J Immunol. 2006; 176:284-290. doi: 10.4049/jimmunol.176.1.284

23. Gabrilovich DI, Ostrand-Rosenberg S, Bronte V. Coordinated regulation of myeloid cells by tumours. Nat Rev Immunol. 2012; 12:253-268. doi: 10.1038/nri3175

24. Hye WK, Torres D, Wald L, Weissleder R, Bogdanov AA. Targeted imaging of human endothelial-specific marker in a model of adoptive cell transfer. Lab Invest. 2006; 86:599-609. doi: 10.1038/labinvest.3700421

25. Nasu K, Itoh H, Yuge A, Kawano Y, Yoshimatsu J, Narahara $\mathrm{H}$, et al. Interleukin- $1 \beta$ regulates vascular endothelial growth factor and soluble fms-like tyrosine kinase-1 secretion by human oviductal epithelial cells and stromal fibroblasts. Gynecol Endocrinol. 2006; 22:495-500. doi: $10.1080 / 08916930600929487$

26. Qin SL, Li TS, Takahashi M, Hamano K. In vitro assessment of the effect of interleukin- $1 \beta$ on angiogenic potential of bone marrow cells. Circ J. 2006. doi: 10.1253/circj.70.1195

27. Prudovsky I, Mandinova A, Soldi R, Bagala C, Graziani I, Landriscina $\mathrm{M}$, et al. The non-classical export routes: FGF1 and IL-1 $\alpha$ point the way. J. Cell Sci. 2003; doi: 10.1242/ jes. 00872

28. Tannahill GM, Curtis AM, Adamik J, Palsson-Mcdermott EM, McGettrick AF, Goel G, et al. Succinate is an inflammatory signal that induces IL- $1 \beta$ through HIF-1 $\alpha$. Nature. 2013; 496:238-242. doi: 10.1038/nature11986
29. Oh H, Grinberg-Bleyer Y, Liao W, Maloney D, Wang P, $\mathrm{Wu} Z$, et al. An NF- $\kappa \mathrm{B}$ transcription-factor-dependent lineage-specific transcriptional program promotes regulatory $\mathrm{T}$ cell identity and function. Immunity. 2017; 47:450-465.e5. doi: 10.1016/j.immuni.2017.08.010

30. Anderson NM, Simon MC. The tumor microenvironment. Curr Biol. 2020; 30:R921-R925. doi: 10.1016/J. CUB.2020.06.081

31. Lakins MA, Ghorani E, Munir H, Martins CP, Shields JD. Cancer-associated fibroblasts induce antigen-specific deletion of CD8 + T Cells to protect tumour cells. Nat Commun. 2018; 9. doi: 10.1038/s41467-018-03347-0

32. Gatenby RA, Gawlinski ET, Gmitro AF, Kaylor B, Gillies RJ. Acid-mediated tumor invasion: A multidisciplinary study. Cancer Res. 2006; 66:5216-5223. doi: 10.1158/00085472.CAN-05-4193

33. Moellering RE, Black KC, Krishnamurty C, Baggett BK, Stafford P, Rain M, et al. Acid treatment of melanoma cells selects for invasive phenotypes. Clin Exp Metastasis. 2008; 25:411-425. doi: 10.1007/s10585-008-9145-7

34. Glunde K, Guggino SE, Solaiyappan M, Pathak AP, Ichikawa Y, Bhujwalla ZM. Extracellular acidification alters lysosomal trafficking in human breast cancer cells. Neoplasia. 2003; 5:533-545. doi: 10.1016/s1476-5586(03)80037-4

35. Švastová E, Žilka N, Zat’ovičová M, Gibadulinová A, Čiampor F, Pastorek J, et al. Carbonic anhydrase IX reduces E-cadherin-mediated adhesion of MDCK cells via interaction with $\beta$-catenin. Exp Cell Res. 2003; 290:332-345. doi: $10.1016 /$ S0014-4827(03)00351-3

36. Pilon-Thomas S, Kodumudi KN, El-Kenawi AE, Russell S, Weber AM, Luddy K, et al. Neutralization of tumor acidity improves antitumor responses to immunotherapy. Cancer Res. 2016; 76:1381-1390. doi: 10.1158/0008-5472.CAN-15-1743

37. Calcinotto A, Filipazzi P, Grioni M, Iero M, De Milito A, Ricupito A, et al. Modulation of microenvironment acidity reverses anergy in human and murine tumor-infiltrating T lymphocytes. Cancer Res. 2012; 72:2746-2756. doi: 10.1158/0008-5472.CAN-11-1272

38. Raghunand N, Mahoney BP, Gillies RJ. Tumor acidity, ion trapping and chemotherapeutics: II. pH-dependent partition coefficients predict importance of ion trapping on pharmacokinetics of weakly basic chemotherapeutic agents. Biochem Pharmacol. 2003; 66:1219-1229. doi: 10.1016/ $\underline{\text { S0006-2952(03)00468-4 }}$

39. Mahoney BP, Raghunand N, Baggett B, Gillies RJ. Tumor acidity, ion trapping and chemotherapeutics: I. Acid pH affects the distribution of chemotherapeutic agents in vitro. Biochem Pharmacol. 2003; 66:1207-1218. doi: 10.1016/S00062952(03)00467-2

40. Gerweck LE, Vijayappa S, Kozin S. Tumor pH controls the in vivo efficacy of weak acid and base chemotherapeutics. Mol Cancer Ther. 2006; 5:1275-1279. doi: 10.1158/15357163.MCT-06-0024 
41. Salerno M, Przewloka T, Fokt I, Priebe W, Garnier-Suillerot A Preferential efflux by P-glycoprotein, but not MRP1, of compounds containing a free electron donor amine. Biochem Pharmacol. 2002; 63:1471-1479. doi: 10.1016/S00062952(02)00895-X

42. Thews O, Gassner B, Kelleher DK, Schwerdt G, Gekle M. Impact of extracellular acidity on the activity of P-glycoprotein and the cytotoxicity of chemotherapeutic drugs. Neoplasia. 2006; 8:143-152. doi: 10.1593/neo.05697

43. Lotz C, Kelleher DK, Gassner B, Gekle M, Vaupel P, Thews O. Role of the tumor microenvironment in the activity and expression of the p-glycoprotein in human colon carcinoma cells. Oncol Rep. 2007; 17:239-244. doi: 10.3892/ or.17.1.239

44. Seabra AB, Paula AJ, De Lima R, Alves OL, Durán N. Nanotoxicity of graphene and graphene oxide. Chem Res Toxicol. 2014; 27:159-168. doi: 10.1021/TX400385X

45. Lalwani G, D’Agati M, Khan AM, Sitharaman B. Toxicology of graphene-based nanomaterials. Adv Drug Deliv Rev. 2016; 105:109-144. doi: 10.1016/J.ADDR.2016.04.028

46. Li B, Yang J, Huang Q, Zhang Y, Peng C, Zhang Y, et al. Biodistribution and pulmonary toxicity of intratracheally instilled graphene oxide in mice. NPG Asia Mater. 201354. 2013; 5:e44-e44. doi: 10.1038/am.2013.7

47. Liu JH, Yang ST, Wang H, Chang Y, Cao A, Liu Y. Effect of size and dose on the biodistribution of graphene oxide in mice. Nanomedicine (Lond). 2012;7(12):1801-1812. doi: $10.2217 / \mathrm{Nnm} .12 .60$

48. Yang K, Gong H, Shi X, Wan J, Zhang Y, Liu Z. In vivo biodistribution and toxicology of functionalized nano-graphene oxide in mice after oral and intraperitoneal administration. Biomaterials. 2013; 34:2787-2795. doi: 10.1016/J.BIOMATERIALS.2013.01.001

49. Yue H, Wei W, Yue Z, Wang B, Luo N, Gao Y, et al. The role of the lateral dimension of graphene oxide in the regulation of cellular responses. Biomaterials. 2012; 33:4013-4021. doi: 10.1016/J.BIOMATERIALS.2012.02.021

50. Deng X, Liang H, Yang W, Shao Z. Polarization and function of tumor-associated macrophages mediate graphene oxide-induced photothermal cancer therapy. J Photochem Photobiol. B Biol. 2020; 208:111913. doi: 10.1016/J.JPHOTOBIOL.2020.111913

51. Shen ZY, Shen BQ, Shen AJ, Zhu XH. Cavitation-enhanced delivery of the nanomaterial graphene oxide-doxorubicin to hepatic tumors in nude mice using $20 \mathrm{kHz}$ low-frequency ultrasound and microbubbles. J Nanomater. 2020:. doi: $10.1155 / 2020 / 3136078$

52. Abdelhalim AOE, Sharoyko VV, Ageev SV, Farafonov VS, Nerukh DA, Postnov VN, et al. Graphene oxide of extra high oxidation: A wafer for loading guest molecules. J Phys Chem Lett. 2021;10015-10024. doi: 10.1021/ACS.JPCLETT.1C02766
53. Abdelhalim AOE, Sharoyko VV, Meshcheriakov AA, Luttsev MD, Potanin AA, Iamalova NR, et al. Synthesis, characterisation and biocompatibility of graphene-L-methionine nanomaterial. J Mol Liq. 2020; 314:113605. doi: 10.1016/j.molliq.2020.113605

54. Abdelhalim AOE, Sharoyko VV, Meshcheriakov AA, Martynova SD, Ageev SV, Iurev GO, et al., Reduction and functionalization of graphene oxide with L-cysteine: Synthesis, characterization and biocompatibility. Nanomedicine Nanotechnology, Biol Med. 2020; 29:102284. doi: 10.1016/j. $\underline{\text { nano.2020.102284 }}$

55. Li Q, Shi Z, Zhang F, Zeng W, Zhu D, Mei L, Symphony of nanomaterials and immunotherapy based on the cancer-immunity cycle. Acta Pharm Sin B. 2021; doi: 10.1016/J. APSB.2021.05.031

56. Kaplan A, Yuan Z, Benck JD, Govind Rajan A, Chu XS, Wang QH, et al. Current and future directions in electron transfer chemistry of graphene. Chem Soc Rev. 2017; 46:4530-4571. doi: 10.1039/c7cs00181a

57. Sun Z, James DK, Tour JM. Graphene chemistry: synthesis and manipulation. J Phys Chem Lett. 2011; 2:2425-2432. doi: $10.1021 /$ jz201000a

58. Loh KP, Bao Q, Ang PK, Yang J. The chemistry of graphene. J Mater Chem. 2010; 20:2277-2289. doi: 10.1039/ b920539j

59. Sturala J, Luxa J, Pumera M, Sofer Z. Frontispiece: Chemistry of graphene derivatives: Synthesis, applications, and perspectives. Chem A Eur J. 2018; 24:. doi: 10.1002/ chem.201882361

60. Gao W. The chemistry of graphene oxide, in: Graphene Oxide Reduct. Recipes, Spectrosc. Appl., Springer Int Publishing, 2015: pp. 61-95. doi: 10.1007/978-3-319-15500-5 3

61. Eigler S, Hirsch A. Chemistry with graphene and graphene oxide - Challenges for synthetic chemists. Angew Chemie-Int Ed. 2014; 53:7720-7738. doi: 10.1002/ anie. 201402780

62. Lavin-Lopez MP, Paton-Carrero A, Sanchez-Silva L, Valverde JL, Romero A. Influence of the reduction strategy in the synthesis of reduced graphene oxide. Adv Powder Technol. 2017; 28:3195-3203. doi: 10.1016/j.apt.2017.09.032

63. Geim AK, Novoselov KS. The rise of graphene. Nat Mater. 2007; 6:183-191. doi: 10.1038/nmat1849

64. [Brodie BC, XIII. On the atomic weight of graphite. Philos Trans R Soc London. 1859; 149:249-259.

65. Hummers WS, Offeman RE. Preparation of graphitic oxide. J Am Chem Soc. 1958; 80:1339. doi: 10.1021/ ja01539a017

66. Eskiizmir G, Baskin Y, Yapici K. Graphene-based nanomaterials in cancer treatment and diagnosis, in: Fullerenes, Graphenes Nanotub. A Pharm. Approach, Elsevier, 2018: pp. 331-374. doi: 10.1016/B978-0-12-813691-1.00009-9 
67. Wang H, Gu W, Xiao N, Ye L, Xu Q. Chlorotoxin-conjugated graphene oxide for targeted delivery of an anticancer drug. Int J Nanomedicine. 2014; 9:1433-1442. doi: 10.2147/ IJN.S58783

68. Kim H, Namgung R, Singha K, Oh IK, Kim WJ. Graphene oxide-polyethylenimine nanoconstruct as a gene delivery vector and bioimaging tool. Bioconjug Chem. 2011; 22:25582567. doi: $10.1021 / \mathrm{bc} 200397$

69. Lee J, Kim J, Kim S, Min DH. Biosensors based on graphene oxide and its biomedical application. Adv Drug Deliv Rev. 2016; 105:275-287. doi: 10.1016/j.addr.2016.06.001

70. Innocenzi P, Stagi L. Carbon-based antiviral nanomaterials: Graphene, C-dots, and fullerenes. A perspective. Chem. Sci. 2020; 11:6606-6622. doi: 10.1039/d0sc02658a

71. Szunerits S, Boukherroub R. Antibacterial activity of graphene-based materials. J Mater Chem. B. 2016; 4:68926912. doi: $10.1039 /$ c6tb01647b

72. Li C, Wang X, Chen F, Zhang C, Zhi X, Wang K, et al. The antifungal activity of graphene oxide-silver nanocomposites. Biomaterials. 2013; 34:3882-3890. doi: 10.1016/j.biomaterials.2013.02.001

73. Zhang L, Xia J, Zhao Q, Liu L, Zhang Z. Functional graphene oxide as a nanocarrier for controlled loading and targeted delivery of mixed anticancer drugs. Small. 2010; 6:537-544. doi: 10.1002/smll.200901680

74. Fan L, Ge H, Zou S, Xiao Y, Wen H, Li Y, et al. Sodium alginate conjugated graphene oxide as a new carrier for drug delivery system. Int J Biol Macromol. 2016; 93:582-590. doi: 10.1016/j.ijbiomac.2016.09.026

75. Qin XC, Guo ZY, Liu ZM, Zhang W, Wan MM, Yang BW. Folic acid-conjugated graphene oxide for cancer targeted chemo-photothermal therapy. J Photochem Photobiol B Biol. 2013; 120:156-162. doi: 10.1016/j.jphotobiol.2012.12.005

76. Huang P, Xu C, Lin J, Wang C, Wang X, Zhang C, et al. Folic acid-conjugated graphene oxide loaded with photosensitizers for targeting photodynamic therapy. Theranostics. 2012; 1:240-250. doi: 10.7150/thno/v01p0240

77. Tiwari H, Karki N, Pal M, Basak S, Verma RK, Bal R, et al. Functionalized graphene oxide as a nanocarrier for dual drug delivery applications: The synergistic effect of quercetin and gefitinib against ovarian cancer cells. Colloids Surfaces B Biointerfaces. 2019; 178:452-459. doi: 10.1016/j.colsurfb.2019.03.037

78. Deb A, Vimala R. Camptothecin loaded graphene oxide nanoparticle functionalized with polyethylene glycol and folic acid for anticancer drug delivery. J Drug Deliv Sci Technol. 2018; 43:333-342. doi: 10.1016/j.jddst.2017.10.025

79. Deb A, Andrews NG, Raghavan V. Natural polymer functionalized graphene oxide for co-delivery of anticancer drugs: In-vitro and in-vivo. Int J Biol Macromol. 2018; 113:515-525. doi: 10.1016/j.ijbiomac.2018.02.153

80. Pei X, Zhu Z, Gan Z, Chen J, Zhang X, Cheng X, et al. PEGylated nano-graphene oxide as a nanocarrier for delivering mixed anticancer drugs to improve anticancer activity. Sci Rep. 2020; 10:1-15. doi: 10.1038/s41598-020-59624-w
81. Bullo S, Buskaran K, Baby R, Dorniani D, Fakurazi S, Hussein MZ. Dual drugs anticancer nanoformulation using graphene oxide-PEG as nanocarrier for protocatechuic acid and chlorogenic acid. Pharm Res. 2019; 36:91. doi: 10.1007/ $\underline{\text { s11095-019-2621-8 }}$

82. Gong P, Zhao Q, Dai D, Zhang S, Tian Z, Sun L, et al. Functionalized ultrasmall fluorinated graphene with high NIR absorbance for controlled delivery of mixed anticancer drugs. Chem- A Eur J. 2017; 23:17531-17541. doi: 10.1002/ chem.201702917

83. Gong P, Du J, Wang D, Cao B, Tian M, Wang Y, et al. Fluorinated graphene as an anticancer nanocarrier: An experimental and DFT study. J Mater Chem B. 2018; 6:27692777. doi: $10.1039 / \mathrm{c} 8 \mathrm{tb} 00102 \mathrm{~b}$

84. Shim G, Kim JY, Han J, Chung SW, Lee S, Byun Y, et al. Reduced graphene oxide nanosheets coated with an anti-angiogenic anticancer low-molecular-weight heparin derivative for delivery of anticancer drugs. J Control Release. 2014; 189:80-89. doi: 10.1016/j.jconrel.2014.06.026

85. Rosli NF, Fojtů M, Fisher AC, Pumera M. Graphene oxide nanoplatelets potentiate anticancer effect of cisplatin in human lung cancer cells. Langmuir. 2019; 35:3176-3182. doi: 10.1021/acs.langmuir.8b03086

86. Pooresmaeil M, Namazi H. $\beta$-Cyclodextrin grafted magnetic graphene oxide applicable as cancer drug delivery agent: Synthesis and characterization. Mater Chem Phys. 2018; 218:62-69. doi: 10.1016/j.matchemphys.2018.07.022

87. Ma N, Liu J, He W, Li Z, Luan Y, Song Y, et al. Folic acidgrafted bovine serum albumin decorated graphene oxide: An efficient drug carrier for targeted cancer therapy. J Colloid Interface Sci. 2017; 490:598-607. doi: 10.1016/j. jcis.2016.11.097

88. Tian J, Luo Y, Huang L, Feng Y, Ju H, Yu BY. Pegylated folate and peptide-decorated graphene oxide nanovehicle for in vivo targeted delivery of anticancer drugs and therapeutic self-monitoring. Biosens Bioelectron. 2016; 80:519-524. doi: 10.1016/j.bios.2016.02.018

89. Javanbakht S, Namazi H. Doxorubicin loaded carboxymethyl cellulose/graphene quantum dot nanocomposite hydrogel films as a potential anticancer drug delivery system. Mater Sci Eng C. 2018; 87:50-59. doi: 10.1016/j. $\underline{\text { msec.2018.02.010 }}$

90. Karki N, Tiwari H, Pal M, Chaurasia A, Bal R, Joshi P, et al. Functionalized graphene oxides for drug loading, release and delivery of poorly water soluble anticancer drug: A comparative study. Colloids Surfaces B Biointerfaces. 2018; 169:265-272. doi: 10.1016/j.colsurfb.2018.05.022 


\title{
Взаимное влияние опухолевых клеток и клеток микроокружения опухоли. Перспективы манипулирования опухолевым микроокружением с помощью наноматериалов
}

\author{
Анна М. Малкова ${ }^{1,2}$, Сергей В. Агеев ${ }^{1,2}$, Абделсаттар О. Е. Абделхалим ${ }^{2,3}$, Олег Е. Молчанов ${ }^{4}$, Дмитрий Н. Майстренко ${ }^{4}$, \\ Константин Н. Семенов ${ }^{1,2,4}$, Владимир В. Шаройко ${ }^{1,2,4}$ \\ ${ }^{1}$ Первый Санкт-Петербургский государственный медицинский университет им. акад. И. П. Павлова, Санкт-Петербург, \\ Россия \\ ${ }^{2}$ Институт химии, Санкт-Петербургский государственный университет, Санкт-Петербург, Россия \\ ${ }^{3}$ Отдел исследования окружающей среды, Национальный центр социальных и криминологических исследований, Гиза, \\ Арабская Республика Египет \\ ${ }^{4}$ Российский научный центр радиологии и хирургических технологий имени А. М. Гранова, Санкт-Петербург, Россия
}

\section{Резюме}

Развитие и прогрессирование неоплазий происходит одновременно с изменениями окружающей стромы. Раковые клетки могут функционально формировать свое микроокружение за счет секреции различных цитокинов, хемокинов и формирования кислой среды. Данные факторы способствуют дифференциации иммунных клеток по иммуносупрессивному фенотипу, стимулируют синтез ряда ферментов обмена аминокислот, факторов роста, молекул адгезии, что промотирует инвазию, ангиогенез и метастазирование, а также снижает эффективность действия противоопухолевых препаратов и лучевой терапии. Для повышения эффективности химиотерапии возможно использование мультитаргетных углеродных наноматериалов. В частности, наноматериалы на основе модифицированного графена позволяют создавать многокомпонентные терапевтические конструкции, включающие макромолекулы, полимеры и эффекторные агенты. Первоначальные эксперименты с немодифицированными графенами продемонстрировали их токсичность, связанную с их накоплением в паренхиматозных органах и инициированием воспалительных процессов. В последние несколько лет вышла серия работ, в которых продемонстрирована возможность снижения токсичности оксида графена за счет функционализации. В данном обзоре обобщены экспериментальные данные по созданию ковалентных и нековалентных конъюгатов на основе оксида графена и показана их эффективность in vitro на различных опухолевых клеточных линиях. Отдельно представлены немногочисленные данные по влиянию наноматериалов на основе оксида графена на опухолевое микроокружение.

\section{Ключевые слова}

Опухоль, микроокружение, прогрессирование, цитокины, ацидоз, иммунная система, углеродные наноматериалы. 